\title{
Phenolic Combination and Comparison of Antioxidant Activity in Three Different Alcoholic Extracts of Dracocephalum moldavica $\mathbf{L}$.
}

\author{
Behnaz Aslanipour ${ }^{1 *}$, Reza Heidari', Neda Farnad ${ }^{2}$ \\ ${ }^{1}$ Graduate School of Natural and Applied Science, Ege University, 35100 Bornova/Izmir, Turkey \\ ${ }^{2}$ Department of Biology, Faculty of Science, Urmia University, Urmia, Iran.
}

\section{A R T I C LE IN F O}

\section{Research Article}

Received 31 May 2016

Accepted 18 February 2017

Keywords:

Moldavian balm

Aantioxidant activity

Phenols

Flavonoids

Anthocyanin

HPLC

\section{A B S T R A C T}

Dracocephalum moldavica $\mathrm{L}$. has been used as both treatment of coronary heart disorders and food supplements. In the present study, determination of total phenolic and flavonoid content in methanol, ethanol and methanol/ethanol extracts of leaf was studied in Iranian Moldavian balm for the first time. Antioxidant activity of the studied plant was also measured. The methanol extract had the highest phenolic and flavonoid content, anthocyanin, DPPH and $\mathrm{H}_{2} \mathrm{O}_{2}$ radical scavenging activity. The ethanol extract showed the least amount of all. The methanol/ethanol extract showed the highest amount in two oxides including nitric and superoxide radical scavenging activities; it also showed the highest Ferric Reducing Ability Power. The obtained chromatograms of the plant using High Performance Liquid Chromatography showed that the highest and the lowest found phenolic compounds were caffeic acid and vanilic acid, respectively. The results show that this plant is a suitable natural antioxidant to reduce the oxidative stress in human being.

\footnotetext{
*Corresponding Author:

E-mail: behnaz_aslanipour@yahoo.com
}

\section{Introduction}

Plants have been used for treating different kinds of disease in our ancient traditional method of medicine. Plants make many chemical compounds that are active for many various biological functions. Recently the focus of pharmacologs has been on the development of new drugs obtained from plants (Ivanova et al., 2005). Herbal compounds are also used as preservatives in foods and cosmetics (Makari et al., 2008).

Phenols and flavonoids are essential compounds of medical plants containing antibacterial, antioxidant and antitumor properties; actually these compounds have been proved as potential preservatives (Nychas et al., 2003). Antioxidants have been shown to counteract oxidative stress in organisms and they have the ability of increasing the risk of chronic and degenerative diseases such as atherosclerosis, cancer and diabetes. Natural antioxidant compounds obtained from plants are much healthier and safer than those produced synthetically (Hentschel et al., 2002; Dastmalchi et al., 2007). Phenolic compounds known as hydrophilic antioxidants and together with Pneumatic cell metabolisms are produced to defend injured plants against pathogens (Bors et al., 1999). They can scavenge free radicals, break radical chain reactions, and chelate metals. Reactive oxygen species (ROS) having lots of pathological effects like DNA damage, carcinogenesis and various degenerative disorders such as cardiovascular diseases, aging and neurodegenerative diseases are generated in living organisms during metabolism (Ahmad et al., 2011; Noda et al., 1997; Gyamfi et al; 2002).

The genus Moldavian balm (Dracocephalum moldavica L.) from Lamiaceae (Labiatae) family has been used for many purposes. This family is well known as a rich source of essences and phenolic compounds (Hentschel et al., 2002). It is an annual herbaceous aromatic plant native to some areas of central Asia and naturalized in central and Eastern Europe. It is mostly found in northern and northwestern parts of Iran, especially in mountains of West Azerbaijan province. Aqueous extracts from Dracocephalum moldavica is distilled and used as a beverage and a cardiotonic agent in the folk medicine of Iran (Rechinger, 1986). Moldavian balm containing essential compounds is commonly consumed for medical and nutritional purposes such as stomach treatment, liver disorders, congestion, headaches and cardio protection in different parts of the world. It has antitumor properties (Chachoyan and Oganesyan, 1996), liver disorder treating properties (Chinese Pharmacopoeia 
Commission, 1999), antimicrobial and assedative (ElGengaihi and Wahba 1995), peripheral antinociceptive and anti-inflammatory activity (Le Bars D et al., 2001). Moldavian balm can also be used as a food ingredient, herbal drug and a demulcent in the treatment of fevers headache and toothache (Hentschel et al., 2002; Proestos et al., 2004).

Geographic location, climate and cultivar are some of the most effective external factors in composition content of the plants; So that, the plants cultivated from different parts of the world may be containing different effective materials with totally different bioactivities. (Lee and Talcott, 2004).

Very little research has been done regarding the antioxidant activity and nonvolatile chemistry of Moldavian balm; therefore less information has been published regarding antioxidative properties of Moldavian balm (Kakasy et al., 2002; Povilaityte et al., 2001; Povilaityte and Venskutonis, 2000). Solvents show various extraction capabilities depending not only on structure of their own but also on the structure of the solute; So that the extractive effect of phenolic compounds highly depends on the organic solvent used for extraction. The present study focuses on evaluation of the antioxidant activities of different leaf extractions of Peppermint gathered from Iran (Sardasht in West Azerbaijan province) and introduction of the best extraction method among three different alcoholic extracts. Furthermore, this study tries to determine the total phenolic compounds and antioxidant activities of leaf part of Moldavian balm and to analyze the main phenolic compounds in the extract of leaf by high performance liquid chromatography (HPLC) method.

\section{Materials and Methods}

\section{Chemicals}

1-1-diphenyl-2-picrylhdrazyl (DPPH) was bought in from Sigma-Aldrich Company Ltd, Gillingham, UK. The solvents, all other materials and reagents were HPLC and analytical grade purchased from Merck in Germany.

\section{Plant Material}

The plant Moldavian balm (European Dracocephalum moldavica L.) was collected from the mountains of Sardasht city of West Azerbaijan Province in May 2012. The material was identified and confirmed by Dr. Abbas Siami and was entrusted to the herbarium of Science Faculty, Urmia University, Urmia, Iran.

\section{Preparation of Extracts}

The leaf parts of the Moldavian balm plant were cut and dried in a dark place in the room temperature at $25^{\circ} \mathrm{C}$, then these dried parts of Moldavian balm were powdered in a mixture grinder. Separately $2 \mathrm{~g}$ of powdered sample was extracted for $3 \mathrm{~h}$ with $25 \mathrm{~mL}$ of different solvents including methanol, ethanol, and methanol/ethanol (1:1) at room temperature on an orbital shaker set at $200 \mathrm{rpm}$ due to extraction in three various dishes at low speed. After filtration with Whatman filter paper No.1 (Whatman
Ltd., England using vacuum pump), the residue was reextracted in the similar way to get the maximum compounds by adding $75 \mathrm{~mL}$ solvent to make up the final extract $(100 \mathrm{~mL})$. The concentrated extracts were kept in dark bottles at $4^{\circ} \mathrm{C}$ for being utilized. Light exposure was avoided during the extraction process.

\section{Determination of Total Phenolic Content (TPC)}

Total phenolic content (TPC) of the studied plant was measured refer to the Folin-Ciocalteu colorimetric method with a little modification (Kahkonen et al., 1999). To start with, Folin Ciocalteu's phenol reagent $(1 \mathrm{~mL})$ (and 7.5\% w/v Na2CO3 $(0.8 \mathrm{~mL})$ were added to sample $\mathrm{M}, \mathrm{E}$ and methanol/ethanol ME extracts $(20 \mu \mathrm{L})$, afterwards the solvent placed in the room temperature for $30 \mathrm{~min}$ to be incubated at $25^{\circ} \mathrm{C}$ in a dark place. Finally, the absorbance of the final reaction was determined in $765 \mathrm{~nm}$. The results were expressed in terms of gallic acid equivalents/100 g Moldavian balm powder. (The calibration equation for Gallic acid: $\mathrm{y}=0.042 \mathrm{x}-0.023, \mathrm{R}^{2}=0.998$ ).

\section{Determination of Total Flavonoid Content (TFC)}

Total flavonoid content (TFC) of the Moldavian balm was measured by using the method of aluminum chloride colorimetric (Chanda and Dave, 2009) with a little modification. During this study, deionized water $(1 \mathrm{~mL})$ was added to $20 \mu \mathrm{L}$ of plant extract; then $0.075 \mathrm{~mL}$ $\mathrm{NaNO}_{2}(5 \%)$ was added to the mixture and after 5 min staying in room temperature, $0.15 \mathrm{~mL}$ of $10 \%$ $\mathrm{AlCl} 3{ }_{6} 6 \mathrm{H}_{2} \mathrm{O}$ was added into the solvent and was stayed for $6 \mathrm{~min}$ in room temperature again; adding $0.5 \mathrm{~mL}$ $\mathrm{NaOH}(\mathrm{mol} / \mathrm{L})$ made the solvent complete; finally, the outcome was reached to the final volume of $3 \mathrm{~mL}$ using deionized water. The absorbance of the final mixture was measured in $510 \mathrm{~nm}$. The results were expressed in terms of g quercetin equivalents /100 g Moldavian balm powder (The calibration equation for quercetin: $\mathrm{y}=0.077 \mathrm{x}-$ $\left.0.013, \mathrm{R}^{2}=0.997\right)$.

\section{Determination of Ferric Reducing Ability Power (FRAP)}

The FRAP was determined using FRAP assay (Benzieet al., 2002) with some modifications. The FRAP solvent included $5 \mathrm{~mL}$ of $10 \mathrm{mMol} / \mathrm{L}$ TPTZ $(2,4,6-$ tripyridyl- s- triazine) solution in $40 \mathrm{mM} \mathrm{HCl}, 2.5 \mathrm{~mL}$ of $20 \mathrm{mM} \mathrm{FeCl}_{3}$, and $25 \mathrm{~mL}$ of $0.3 \mathrm{M}$ acetate buffer (pH 3.6) $(0.3 \mathrm{~mol} / \mathrm{L}, \mathrm{pH}=3.6) .3 \mathrm{~mL}$ FRAP was added to $100 \mu \mathrm{L}$ of mixed sample and the final solution was measured at the absorbance of $593 \mathrm{~nm}$ after incubation at $37^{\circ} \mathrm{C}$ for 10 min. Methanolic solutions of known Fe (II) concentration, in the range of $0.6-10 \mu \mathrm{mol} / \mathrm{L}\left(\mathrm{FeSO}_{4}\right)$, were used for obtaining the calibration curve. The FRAP value shows the ratio between the slope of the linear scheme for reducing $\mathrm{Fe}^{3+}$-TPTZ reagent by Moldavian balm extract in comparison with the slope of the scheme for $\mathrm{FeSO}_{4}$.

Determination of superoxide radical scavenging activity

The system of pyrogallol autoxidation was used for evaluation of superoxide scavenging (Jing and Zhao, 1995). A volume of $9 \mathrm{~mL}$ Tris- $\mathrm{HCl}$ buffer solution $(50 \mathrm{mmol} / \mathrm{L}, \mathrm{pH}=8.2)$ was added into a test tube, and the 
tube was incubated in a water bath at $25^{\circ} \mathrm{C}$ for $20 \mathrm{~min}$. A volume of $40 \mu \mathrm{L}$ pyrogalol solution $(45 \mathrm{mmol} / \mathrm{L}$ in 10 $\mathrm{mmol} / \mathrm{L} \mathrm{HCl}$ ) which was pre-incubated for $20 \mathrm{~min}$ at $25^{\circ} \mathrm{C}$ was injected to the mentioned tube by a microlitre syringe and mixed together. The absorbance of this solvent showing the speed of pyrogallol autoxidation by being measured at $420 \mathrm{~nm}$ after $5 \mathrm{~min}$. Ascorbic acid was announced as the reference compound. Certain concentration of extract was added to the previous solution and standard into Tris- $\mathrm{HCl}$ buffer solution and indicated the autoxidation speed. The less absorbance of the reaction mixture there was, the more superoxide anion scavenging activity there was. The superoxide radical scavenging activity using the following equation:

$$
\text { Superoxide scavenging activity } \%=\frac{A_{0}-A_{1}}{A_{0}} \times 100
$$

Where $\mathrm{A}_{0}$ was the absorbance of control (blank, without extract) and $A_{1}$ was the absorbance of the solution in the presence of ascorbic acid and the extract.

\section{Determination of Hydrogen Peroxide Radical Scavenging Activity $\left(\mathrm{H}_{2} \mathrm{O}_{2}\right)$}

A method to determine the $\mathrm{H}_{2} \mathrm{O}_{2}$ scavenging ability previously mentioned was used with a little modification (Ruch et al., 1989). Moldavian balm extracts $(2 \mathrm{mg} / \mathrm{mL})$ were dissolved in $3 \mathrm{~mL}$ of a $0.1 \mathrm{M}$ phosphate buffer $(\mathrm{pH}=7.4)$ solution and mixed with $600 \mu \mathrm{L}$ of a $43 \mathrm{mM}$ solution of hydrogen peroxide previously prepared in the same buffer. A blank solution was prepared the same way without presence of $\mathrm{H}_{2} \mathrm{O}_{2}$. The absorbance of the solutions was measured for recognizing the concentration of hydrogen peroxide at $230 \mathrm{~nm}$. Gallic acid was used as the reference compound. The hydrogen scavenging activity was calculated using the following equation:

$$
\mathrm{H}_{2} \mathrm{O}_{2} \text { scavenging activity } \%=\frac{A_{0}-A_{1}}{A_{0}} \times 100
$$

Where $\mathrm{A}_{0}$ was the absorbance of control (blank, without extract) and $A_{1}$ was the absorbance of the solution in the presence of the extract and gallic acid.

Determination of DPPH Radical Scavenging Activity

DPPH radical scavenging activity in Moldavian balm extracts were determined using the method described by Hatano (Hatano et al., 1988). A volume of $40 \mu \mathrm{L}$ of each extract in various concentrations $(3-20 \mathrm{mg} / \mathrm{mL})$ was added to $1 \mathrm{~mL}$ of DPPH (1-1-diphenyl 2-picryl hydrazyl) radical solution dissolved in ethanol with a $0.2 \mathrm{mM}$ final concentration. Two different standards called ascorbic acid and gallic acid $(0.125-20 \mathrm{mg} / \mathrm{mL})$ were reference standards. The different tubes containing the solutions were placed in a dark room for $30 \mathrm{~min}$ to be incubated. The absorbance of mixtures was measured at $520 \mathrm{~nm}$ immediately. The DPPH radical scavenging activity was calculated using the following equation:

$$
\text { DPPH scavenging activity } \%=\frac{A_{0}-A_{1}}{A_{0}} \times 100
$$

$\mathrm{A}_{0}$ was the absorbance of the control (blank, without extract) and $A_{1}$ was the absorbance of the whole materials including extract, ascorbic acid, gallic acid, DPPH.

Determination of Nitric Oxide Radical Inhibition Assay

Nitric oxide radical inhibition can be measured using Griess Ilosvay reaction reaction (Garrat 1964). naphthyl ethylene diamine dihydrochloride $(0.1 \% \mathrm{w} / \mathrm{v})$ was used instead of napthylamine $(5 \%)$. The final combination of mixture $(3 \mathrm{~mL})$ containing phosphate buffer saline $(0.5$ $\mathrm{mL})$, sodium nitroprusside $(10 \mathrm{mM}, 2 \mathrm{~mL})$ and the alcoholic extract of Moldavian balm $(0.5 \mathrm{~mL})$ was incubated at room temperature for $150 \mathrm{~min}$. After incubation, $1 \mathrm{~mL}$ of sulfanilic acid reagent $(0.33 \%$ in $20 \%$ glacial acetic acid) was added to $0.5 \mathrm{~mL}$ of the prepared mixture and allowed to stand for $5 \mathrm{~min}$ for complementation of diazotization. Then, $1 \mathrm{~mL}$ of naphthyl ethylene diamine dihydrochloride was added and allowed to stay at room temperature for $30 \mathrm{~min}$. The final solution had a pinkish color in diffuse light. Ascorbic acid and gallic acid were utilized as the reference compounds. The absorbance of the solutions was measured at $540 \mathrm{~nm}$ in the comparison of blank. The nitric oxide radical scavenging activity was calculated using the following equation.

Nitric oxide scavenging activity $\%=\frac{A_{0}-A_{1}}{A_{0}} \times 100$

Where $\mathrm{A}_{0}$ was the absorbance of the control (blank, without extract) and $A_{1}$ was the absorbance of the whole materials including extract, ascorbic acid and gallic acid.

Determination of Total Anthocyanin Content (TAC)

Total anthocyanin content (TCA) in the studied plant extract was determined utilizing $\mathrm{pH}$-differential method previously described with a little modification (Lee et al., 2005). The whole anthocyanins show the maximum absorbance at $520 \mathrm{~nm}$. The colorless hemiketal form at $\mathrm{pH} 4.5$, and the colored oxonium form predominate at $\mathrm{pH}$ 1.0. The method of $\mathrm{PH}$ differentiation is the reaction producing oxonium forms and permits accurate and rapid measurement of the total anthocyanins. Absorbance of the results was calculated using the following equation:

$$
\mathrm{A}=\left(\mathrm{A}_{520}-\mathrm{A}_{700}\right) \mathrm{pH}_{1.0}-\left(\mathrm{A}_{520}-\mathrm{A}_{700}\right) \mathrm{pH}_{4.5}
$$

The concentration $(\mathrm{mg} / \mathrm{L})$ of each anthocyanin was calculated according to the following equation and expressed as Cyanidin-3-glucoside (Cy-3-glc) equivalents:

$$
\text { Concentration }(\mathrm{mg} / \mathrm{L}) \text { of each anthocyanin }=\frac{A \times M V \times D F \times 10^{2}}{\sum \times L}
$$

$\mathrm{A}$ is the absorbance $=(\mathrm{A}$ of $\mathrm{pH} 1.0-\mathrm{A}$ of $\mathrm{pH} 4.5)$, $\mathrm{MW}$ is the molecular weight $(\mathrm{g} / \mathrm{moL})=449.2 \mathrm{~g} / \mathrm{mol}$ for Cy-3-glc, DF is the dilution factor, $\Sigma$ is the extinction coefficient $(\mathrm{L} \times \mathrm{cm}-1 \times$ mol-1 $)=26,900$ for Cy3-glc, and L (path length in $\mathrm{cm}$ ) $=1$, so result reported is expressed as Cy-3-glc equivalents. 


\section{HPLC Analysis}

For the analysis of HPLC, $1 \mathrm{~g}$ of the powdered and dried plant material was extracted with $50 \%$ methanol/water $(1 \times 10 \mathrm{~mL})$ for $2 \mathrm{~h}$ at room temperature. After that, $1.2 \mathrm{~N} \mathrm{HCl}$ was added to the resulted extract and it was hydrolyzed by reflux method in a water bath for $1 \mathrm{~h}$ (Lin-Chin et al., 2000). Samples were filtered through a $0.45-\mu \mathrm{m}$ pore size syringe-driven filter before injection. A $20 \mu \mathrm{L}$ aliquot of sample solution was separated utilizing a HPLC Knauer system equipped with UV-V detector and a Eurospher 100-5 C-18 column (25 $\mathrm{cm} \times 4.6 \mathrm{~mm} ; 5 \mu \mathrm{m})$ and processed the hydrolysate to qualitative and quantitative analysis (Bajpai et al., 2005). The system includes a mobile phase full of purified water with $2 \%$ acetic acid (A) and acetonitrile (B) at a flow rate of $0.8 \mathrm{~mL} / \mathrm{min}$. Phenolic compounds were eluted under the following conditions: $0.8 \mathrm{~mL} / \mathrm{min}$ flow rate and the temperature was set at $25^{\circ} \mathrm{C}$, isocratic conditions from 0 to 10 minute with $0 \% \mathrm{~B}$, gradient conditions from $0 \%$ to $20 \% \mathrm{~B}$ in $5 \mathrm{~min}$, from $20 \%$ to $25 \% \mathrm{~B}$ in $10 \mathrm{~min}$, from $25 \%$ to $100 \% \mathrm{~B}$ in $15 \mathrm{~min}$, followed by washing and reconditioning the column. Phenolic compounds were detected in a wavelength of $280 \mathrm{~nm}$. Results were gained by using the comparison of peak areas of the samples with those of standards.

\section{Statistical Analysis}

All the investigations were carried out in triplicate. Experimental information was revealed as mean \pm standard deviation (SD). SPSS software, Version 19.0, was used to analyze the data. One-way analysis of variance was provided by ANOVA procedures. Values of $\mathrm{P}<0.05$ were organized as significant utilizing Duncan's multiple range tests to show the differences between means.

\section{Result and Discussion}

\section{Total Phenolic Content (TPC)}

Moldavian balm species are proved to have secondary metabolites like flavonoids and terpenoids. They not only have glycosides, aglycones but also have ohydroxybenzoic, hydroxycinnamic acids (Dastmalchi et al., 2007). There are numerous investigations proving the effect of antioxidant supplementation for reducing and preventing the oxidative stresses (Jahanban Sfahlan et al., 2009). Plant phenolics, strong free radical scavengers, are highly used for prevention of increasing the number of free radicals. In this study, phenolic acids, flavonoids and anthocyanins were the major phenolics analyzed. The TPC of leaf part of the M extract $3.0450 \pm 0.11 \mathrm{~g}$ gallic acid/100 g Moldavian balm dry shown in Table 1 had the highest total phenolic content as compared to the other extracts. The ME extract $(2.308473 \pm 0.97)$ also showed the good amount of total phenolic compound compared to $\mathrm{M}$ extract (1.5673 \pm 0.077$)$.

\section{Total Flavonoid Content (TFC)}

Flavonoids are a ubiquitous member of plant polyphenolic compounds which act as common components with dietary, biological actions. Nowadays, flavonoids have attracted lots of interests of antioxidant studies. There are numerous biomolecules and proteins in living organisms with a significant free radical scavenging actions such as, flavonoids, phenols and other dietary supplements (Patricia et al., 2005). In present study, we have worked on finding and comparing the total flavonoids in different extracts of the leaf part of Dracocephalum moldavica $L$ and the possible mechanisms. The values of TFC demonstrated in Table 2 conclude that $\mathrm{M}$ extract $(1.8813 \pm 0.04 \mathrm{~g}$ quercetin $/ 100 \mathrm{~g}$ Moldavian balm powder) and E (1.25552 $\pm 0.70 \mathrm{~g}$ quercetin /100 g Moldavian balm powder) extracts were the highest and the least amount of total flavonoid content respectively. Also, there was an important point that comparing the TPC and TFC in all extracts shows that $\mathrm{M}$ extract of leaf part of Moldavian balm contains the highest amount of total phenol and flavonoid compounds.

\section{Ferric Reducing Antioxidant Power (FRAP)}

Wide differences of in vitro antioxidant power were resulted in three different extracts of Moldavian balm. The results showed that various extracts of Moldavian balm plant had wide differences. The outcome antioxidant capacity was correlated with the total phenolic contents. The DE (185.4379 $\pm 1.5819 \%)$ and ME (101.4027 $\pm 6.0876 \%)$ extracts had the highest and the least FRAP, respectively shown in Table 3. The E extract was the highest of all but this fact never confirmed that Moldavian balm extracts contain the highest levels of antioxidant compounds because the FRAP activities of extracts were lower than standards.

\section{Superoxide Radical Scavenging Activity}

The superoxide anion is produced by mitochondrial respiration, NADPH oxidase, xanthine oxidase, cyclooxygenase, lipoxygenase, nitric oxidase synthetase (NOS) and cytochrome P450 (30-31-32-33-34-35). Not only phenols but also flavonoids belonging to the class of phenols can gather harmful superoxide radicals effectively. The combination of superoxide and nitric acid peroxynitrite can be a reason of producing toxic compounds such as hydroxyl radical and nitric dioxide (Sainani et al., 1997). Furthermore anions of superoxide can accelerate the autoxidation, thereupon autoxidation don't have the opportunity taking place in the presence of antioxidants collectors. Although anion of superoxide is a weak oxidator, but oxygen and hydroxyl radical can be produced by superoxide which both involve in oxidative stresses (Halliwell, 1995). The capacity of superoxide scavenging activity using the different alcoholic extract of Moldavian balm has been obtained by method of pyrogallol autoxidationin presence of Tris- $\mathrm{HCl}$ buffer. The percentage of scavenging activity was more than $60 \%$ in all the obtained extracts. Respectively, the ME $(56.7226 \pm 1.8564 \%)$ and $\mathrm{E}(44.4327 \pm 6.472 \%)$ extracts had the highest and the least amount of Superoxide radical scavenging activity shown in Table 2 . 
Table 1 Total phenolic, flavonoid and anthocyanin contents of $20 \mathrm{mg} / \mathrm{mL}$ alcoholic extracts of Dracocephalum moldavica L.*

\begin{tabular}{l|ccc}
\hline \multicolumn{1}{c|}{ Extract } & $\begin{array}{c}\text { Total phenols content } \\
(\mathrm{g} \text { Gallic acid/100 } \mathrm{g})\end{array}$ & $\begin{array}{c}\text { Total flavonoid content } \\
(\mathrm{g} \text { Quercetin/100 } \mathrm{g})\end{array}$ & $\begin{array}{c}\text { Anthocyanin contents } \\
(\mathrm{g} / 100 \mathrm{~g})\end{array}$ \\
\hline Methanol & $3.04 \pm 0.1^{\mathrm{c}}$ & $1.88 \pm 0.04^{\mathrm{b}}$ & $0.24 \pm 0.01^{\mathrm{a}}$ \\
Ethanol & $1.56 \pm 0.07^{\mathrm{a}}$ & $1.25 \pm 0.70^{\mathrm{a}}$ & $0.11 \pm 0.01^{\mathrm{b}}$ \\
Methanol/Ethanol $(1: 1)$ & $2.308 \pm 0.9^{\mathrm{b}}$ & $1.70 \pm 0.60^{\mathrm{c}}$ & $0.16 \pm 0.03^{\mathrm{c}}$ \\
\hline \multicolumn{2}{l}{ *Values are presented as mean $\pm \mathrm{SD}(\mathrm{n}=3)$. Values of $\mathrm{P}<0.05$ are regarded as significant. }
\end{tabular}

Table 2 DPPH, nitric oxide and superoxide radical scavenging activities values and IC50 values of $20 \mathrm{mg} / \mathrm{mL}$ alcoholic extracts of Dracocephalum moldavica L.*

\begin{tabular}{l|cccc}
\hline \multicolumn{1}{c|}{ Extract } & IC50 $(\mathrm{mg} / \mathrm{mL})$ & DPPH & NORSA & SRSA \\
\hline Methanol & $3.624 \pm 1.26^{\mathrm{d}}$ & $87.77 \pm 0.31^{\mathrm{a}}$ & $37.60 \pm 1.95^{\mathrm{a}}$ & $44.43 \pm 6.47^{\mathrm{c}}$ \\
Ethanol & $8.040 \pm 0.25^{\mathrm{c}}$ & $60.88 \pm 5.03^{\mathrm{b}}$ & $73.54 \pm 1.63^{\mathrm{c}}$ & $56.72 \pm 1.85^{\mathrm{b}}$ \\
Methanol/Ethanol(1:1) & $2.860 \pm 69^{\mathrm{b}}$ & $25.96 \pm 1.07^{\mathrm{b}}$ & $87.90 \pm 5.28^{\mathrm{a}}$ & $57.14 \pm 1.21^{\mathrm{a}}$ \\
Gallic acid & $0.16 \pm 0.03^{\mathrm{a}}$ & $92.00 \pm 0.35^{\mathrm{c}}$ & $68.28 \pm 2.63^{\mathrm{b}}$ & - \\
Ascorbic acid & $0.18 \pm 0.02^{\mathrm{a}}$ & $91.20 \pm 0.29^{\mathrm{c}}$ & $65.26 \pm 0.99^{\mathrm{b}}$ & $65.61 \pm 1.88^{\mathrm{d}}$ \\
\hline
\end{tabular}

*Values are presented as mean \pm SD $(n=3)$. Values of $\mathrm{P}<0.05$ are regarded as significant. DPPH: DPPH radical scavenging activity\%, NORSA: Nitric oxide radical scavenging activity (\%); SRSA: Superoxide radical Scavenging activity (\%)

\section{Nitric Oxide Radical Scavenging Percentage}

A highly participated reactive molecule in the systems of immune and cardiovascular is called Nitric oxide (NO) which is involved in many physiologic reactions. This nitric oxide generated from sodium nitroprusside reacts with oxygen to form nitrite anion and proxynitrite which are well known as free radicals (Sainani et al., 1997). Under high concentration of $\mathrm{NO}$, a number of extremely reactive nitrogen oxide species, such as $\mathrm{N}_{2} \mathrm{O}_{3}$ and ONOOcan be produced and they cause toxic reactions including lipid peroxidation and DNA modification (Bartasch and Montesano, 1984). The extract inhibits nitrite formation by competing with oxygen. The ME $(87.9095 \pm 5.2856 \%)$ and $\mathrm{M}(37.6074 \pm 1.9518 \%)$ had the highest and the least nitric oxide radical scavenging percentage shown in Table 2. The ME and $\mathrm{E}$ extracts had more nitric oxide radical scavenging percentage than gallic acid $(61.16 \pm 2.89 \%)$ and ascorbic acid $(68.16 \pm 0.90 \%)$ but $\mathrm{M}$ extract had lower nitric oxide radical scavenging percentage than standards.

\section{Hydrogen Peroxide Radical Inhibition Assay}

The toxicity of hydrogen peroxide can be derived from its conversion to other species of ROS such as hydroxyl radical which initiate lipid peroxidation and cause DNA damage (Nakayama et al., 1993). Hydrogen radicals $\left(\mathrm{OH}^{*}\right)$ may be produced by decomposition of $\mathrm{H}_{2} \mathrm{O}_{2}$ into oxygen and water. Thus, removing hydrogen peroxide as well as other ROS is very important to protect lots of cellular compounds such as protein and DNA (Zhao et al., 2008). The hydrogen peroxide scavenging activities of $\mathrm{M}(7.93 \pm 0.658)$ and $\mathrm{E}(4.48 \pm 2.030)$ extracts had the highest and the least scavenging capacity against $\mathrm{H}_{2} \mathrm{O}_{2}$ respectively. The $\mathrm{M}$ extract had more hydrogen peroxide scavenging activity than gallic acid $(16.91 \pm 2.86 \%)$ at a concentration of $2 \mathrm{mg} / \mathrm{mL}$, strongly suggesting that this extract contains the necessary compounds for hydrogen peroxide deletion shown in Table 3.

\section{DPPH Radical Scavenging Assay}

DPPH is a radical with purple color which can get a hydrogen or electron to be a yellow colored compound called diphenyl-picrylhdrazine at $25^{\circ} \mathrm{C}$. Antioxidants can cause a reduction in the DPPH radical and in the absorbance of the different extracts of Moldavian balm (Brand-Williams et al., 1995). The $\mathrm{IC}_{50}$ values were calculated and they are negatively associated with antioxidant activity. The DPPH radical scavenging activity values for gallic acid and ascorbic acid were $93.00 \pm 0.45 \%$ with $\mathrm{IC}_{50}=0.15 \pm 0.01 \quad \mathrm{mg} / \mathrm{mL}$ and $92.30 \pm 0.26 \%$ with $\mathrm{IC}_{50}=0.16 \pm 0.01 \mathrm{mg} / \mathrm{mL}$, respectively. The results showed that the DPPH radical scavenging activities of the $\mathrm{M}$ extract $(87.77 \pm 0.31 \%$, $\left.\mathrm{IC}_{5}=3.624 \pm 1.26\right)$ and $\mathrm{E}$ extract $(60.88 \pm 5.03 \%$, $\left.\mathrm{IC}_{50}=8.040 \pm 0.25\right)$ were significant. The amount of DPPH radical scavenging activity in all extracts was lower than both gallic acid and ascorbic acid shown in Table 2 .

\section{Total Anthocyanin Contents (TAC)}

Anthocyanins are some compounds classified in flavonoids and found in almost all fruit and vegetables. They are not only protectors against oxidative stresses but also reducer of their effects. Table 1 shows the amount of anthocyanin content of the different 3 extracts. Respectively, the M $(0.24 \pm 0.013 \%)$ and E $(0.11 \pm 0.010 \%)$ extracts were the highest and the least TCA shown in Table 1.

\section{HPLC Analysis of the Moldavian Balm Extracts}

The content of phenolic substances was determined by quantitative HPLC analysis after extraction and acid hydrolysis. Analyzing Moldavian balm using HPLC analysis method revealed that some compounds such ferulic acid, caffeic acid, vanilic acid, 1-naphtol, 4hydroxy-benzoic acid, cholorogenic acid were identified. Refer to HPLC analysis caffeic acid $(9.49 \pm 4.97 \mathrm{mg} / 100 \mathrm{~g}$ Moldavian balm powder and vanillic acid $(0.43 \pm 0.008$ $\mathrm{mg} / 100 \mathrm{~g}$ Moldavian balm powder) were the highest and lowest phenolic compound in Moldavian balm respectively. Injection of 9 standards of phenols are represented in figure 1 and figure 2 , and comparison of the obtained chromatogram of the results are shown in Table 5. HPLC analysis proved that Moldavian balm extract contains caffeic acid and 1-naphtol as other phenols which are shown in table 4 , but some phenols like 
ascorbic acid, gallic acid and rutin shown in table 5 were not detected.

Table $3 \mathrm{H}_{2} \mathrm{O}_{2}$ radical scavenging activities and FRAP values of $2 \mathrm{mg} / \mathrm{mL}$ alcoholic extracts of Dracocephalum moldavica $\mathrm{L}^{*}$

\begin{tabular}{l|cc}
\hline \multicolumn{1}{c|}{ Extract } & $\mathrm{H}_{2} \mathrm{O}_{2}$ radical Scavenging activity $(\%)$ & FRAP value $(\mu \mathrm{mol} / 100 \mathrm{~g})$ \\
\hline Methanol & $7.93 \pm 0.65^{\mathrm{d}}$ & $180.98 \pm 1.02^{\mathrm{a}}$ \\
Ethanol & $4.48 \pm 2.030^{\mathrm{c}}$ & $101.40 \pm 6.08^{\mathrm{a}}$ \\
Methanol/Ethanol (1:1) & $6.17 \pm 0.813^{\mathrm{b}}$ & $185.437 \pm 1.58^{\mathrm{a}}$ \\
Gallic acid & $21.81 \pm 2.34^{\mathrm{a}}$ & $811.65 \pm 5.21^{\mathrm{c}}$ \\
Ascorbic acid & - & $521.16 \pm 10.94^{\mathrm{b}}$ \\
\hline
\end{tabular}

Values are presented as mean $\pm \mathrm{SD}(\mathrm{n}=3)$. Values of $\mathrm{P}<0.05$ are regarded as significant

Table 4 Linear calibration curves for the HPLC-UV analysis of the phenolic compounds of extract from Moldavian balm (Dracocephalum moldavica L.).

\begin{tabular}{c|lcccc}
\hline No & \multicolumn{1}{|c}{ Ascorbic acid } & $\begin{array}{c}\text { Retention } \\
\text { Time (min) }\end{array}$ & $\begin{array}{c}\text { Equation of linear Regression (peak } \\
\text { area concentration) }\end{array}$ & $\begin{array}{c}\text { Linear range } \\
(\mathrm{mg} / \mathrm{L})\end{array}$ \\
\hline 1 & Ascorbic acid & 3.6 & $\mathrm{Y}=2 \mathrm{e}+06 \mathrm{X}-1 \mathrm{e}+06$ & 0.998 & $0.005-5$ \\
2 & Rutin & 5.4 & $\mathrm{Y}=\mathrm{E}+06 \mathrm{x}-2 \mathrm{E}+06$ & 0.998 & $0.5-10$ \\
3 & Gallic acid & 7.2 & $\mathrm{Y}=68759 \mathrm{x}+3509.5$ & 0.997 & $0.5-10$ \\
4 & Chlorogenic acid & 10.3 & $\mathrm{Y}=165138 \mathrm{x}-136553$ & 0.989 & $0.5-10$ \\
5 & Ferulic acid & 11.0 & $\mathrm{Y}=83185 \mathrm{x}-1 \mathrm{E}+5$ & 0.988 & $0.5-10$ \\
6 & 4-Hydroxy benzoic acid & 11.4 & $\mathrm{Y}=3 \mathrm{E}+06 \mathrm{X}-29609$ & 0.998 & $1-10$ \\
7 & Vanilic acid & 12 & $\mathrm{Y}=1 \mathrm{E}+06 \mathrm{X}-2 \mathrm{E}+06$ & 0.999 & $0.05-10$ \\
8 & Caffeic acid & 14.7 & $\mathrm{Y}=1 \mathrm{E}+06 \mathrm{X}-76169$ & 0.988 & $1-10$ \\
9 & Naphtol & 22.3 & $\mathrm{Y}=2 \mathrm{e}+06 \mathrm{X}-1 \mathrm{e}+06$ & 0.998 & $1-10$ \\
\hline
\end{tabular}

Table 5 Content of phenolic compounds in extract of Moldavian balm

\begin{tabular}{|c|c|c|}
\hline $\mathrm{No}$ & Phenolic compound & (mg/100 g dragonhead powder) \\
\hline 1 & Ascorbic acid & $\mathrm{Nd}$ \\
\hline 2 & Rutin & $\mathrm{Nd}$ \\
\hline 3 & Gallic acid & $\mathrm{Nd}$ \\
\hline 4 & Chlorogenic acid & $1.57 \pm 0.06$ \\
\hline 5 & Ferulicacid & $4.53 \pm 0.03$ \\
\hline 6 & 4-Hydroxybenzoicacid & $7.23 \pm 0.14$ \\
\hline 7 & Vanilicacid & $0.43 \pm 0.008$ \\
\hline 8 & Caffeicacid & $9.49 \pm 4.97$ \\
\hline 9 & 1-Naphtol & $4.18 \pm 0.14$ \\
\hline
\end{tabular}

Values are presented as mean $\pm \mathrm{SD}(\mathrm{n}=3)$. Values of $\mathrm{p}<0.05$ are regarded as significant. Nd: Not detected.

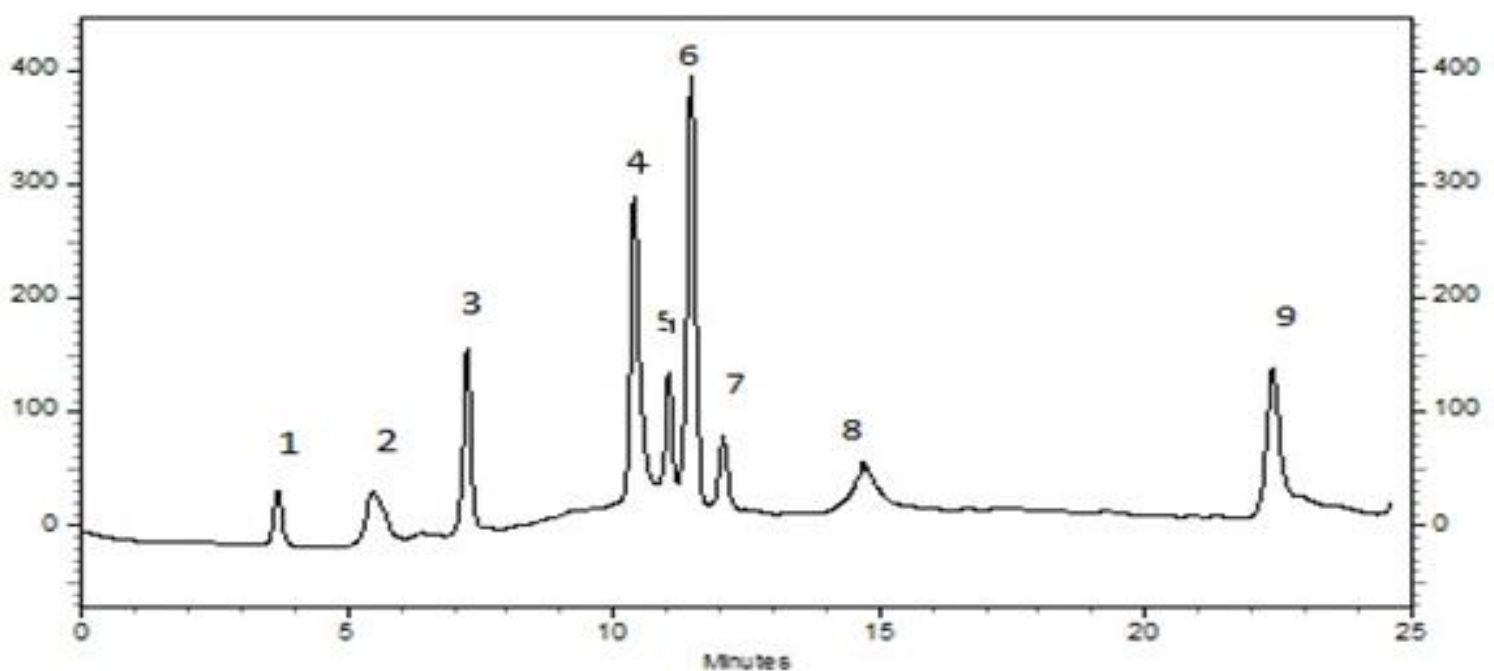

Figure 1 HPLC chromatograms of Moldavian balm extracts at $280 \mathrm{~nm}$. Peak: (1) Ascorbic acid, (2) Rutin, (3) Gallic acid, (4) Chlorogenic acid, (5) Ferulic acid, (6) 4-Hydroxy benzoic acid, (7) Vanilic acid, (8) Caffeic aicd, and (9) 1Naphtol $\mathrm{P}<0.05$ 


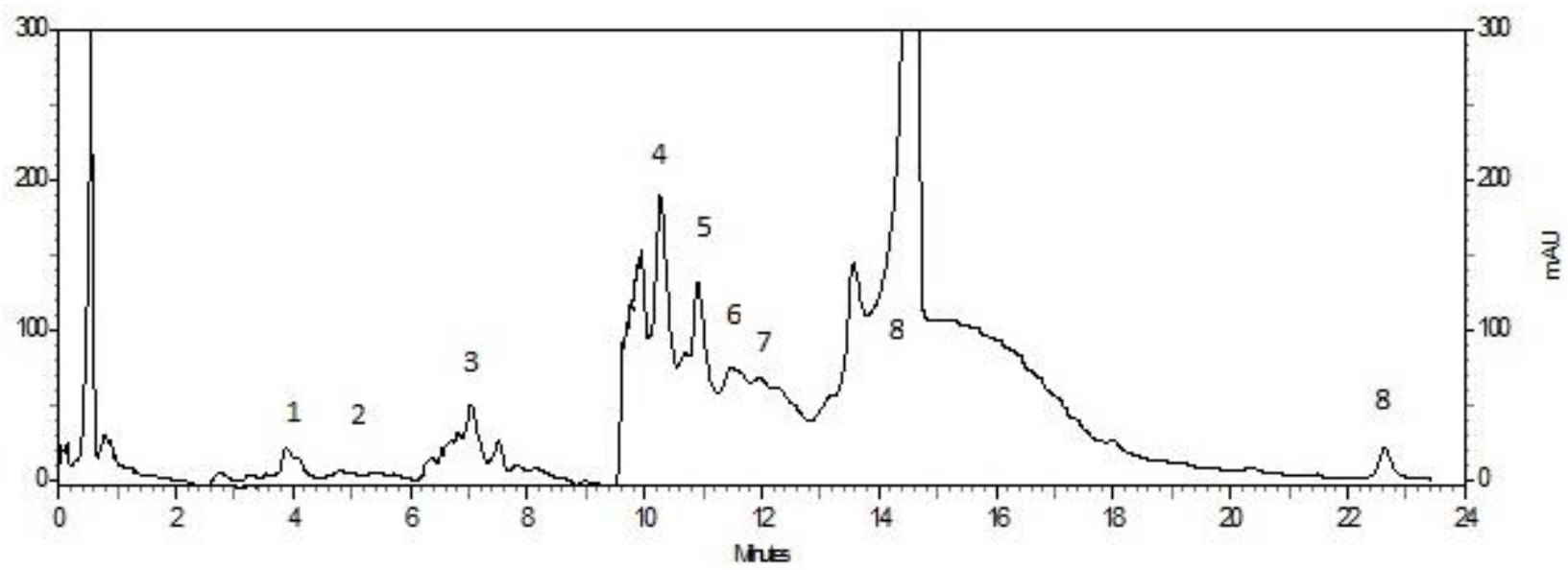

Figure 2 Mixture of standard phenolic compounds at $280 \mathrm{~nm}$. Peak: (1) Ascorbic acid, (2) Rutin, (3) Gallic acid, (4) Chlorogenic acid, (5) Ferulic acid, (6) 4-Hydroxy benzoic acid, (7) Vanilic acid, (8) Caffeic aicd, and (9) 1-Naphtol, p

\section{Conclusion}

The present study showed that Moldavian balm (Dracocephalum moldavica L.) growing in Iran, which is often present in Iranian food and folk medicine, is a strong radical scavenger. The extracts of alcoholic solvents were found to have different levels of antioxidant activity in the systems tested. This could be due to the presence of an enormous amount of flavonoid and phenolic compounds. The study also revealed the possible antioxidant mechanism of the extracts such as electrondonating ability and direct free radical scavenging properties. The high scavenging property of Moldavian balm (Dracocephalum moldavica L.) may be due to hydroxyl groups existing in the phenolic compounds that can scavenge the free radicals. These extracts can be used as easily accessible source of natural antioxidants and a possible food supplement or in pharmaceutical applications. It can also be used in stabilizing food against oxidative deterioration.

\section{References}

Ahmad M, Shah AS, Khan RA, Khan FU, Khan NA, Shah MS, Khan MR. 2011. Antioxidant and antibacterial activity of crude methanolic extract of Euphorbia prostrate collected from District Bannu (Pakistan). African Journal of Pharmacy and Pharmacology 5: 1175-1178.

Bajpai M, Pande A, Tewari SK, Prakash D. 2005. Phenolic contents and antioxidant activity of some food and medicinal plants. International Journal of Food Science and Nutrition 56: 287291.

Bartasch H, Montesano R. 1984. Relevance of nitrosamines to human cancer. Journal of Carcinogenesis 5: 1381-1393.

Benzie FFI, TomLinson B, Szeto YT. 2002. Total antioxidant and ascorbic acid content of fresh fruits and vegetables: implications for dietary planning and food preservation. British Journal of Nutrition, 87: 55-59.

Bors W, Heller W, Michel C, Stettmaier K. 1999. Flavonoids and polyphenols: Chemistry and biology. Handbook of Antioxidants 1996: 409-466.

Brand-Williams W, Cuvelier ME, Berset C. 1995. Use of a free radical method to evaluate antioxidant activity. Journal of Food Science and Technology, 28: 25-30.
Chachoyan AA, Oganesyan GB. 1996. Antitumor activity of some species of family lamiaceae. Rastitel, 32: 59-64.

Chanda S, dave R. 2009. In vitro models for antioxidant activity evaluation andsome medicinal plants possessing antioxidant properties: An overview of African Journal of Microbiology Research, 3: 981-996.

Cosentino F, Patton S, D'Uscio LV, Werner ER. 1998. Tetra hydrobiopterin alters superoxide and nitric oxide release in prehypertensive rats. Journal of Clinical Investigation 101:1530-1537.

Dasstmalchi K, Dorman D, Kosar K, Hiltunen R. 2005. Chemical composition and in vitro antioxidant evaluation of a watersoluble Moldavian Balm (Dracocephalum moldavica L.) extract. Food Science and Technology- Elsevier, 40: 239-248

Kahkonen MP, Hopia AI, Vuorela HJ, Rauha JP, Pihlaja K, Kujala TS. 1999. Antioxidant activity of plant extracts containing phenolic compounds. Journal of Agricultural and Food chemistry, 57: 792-797

El-Gengaihi S, Wahba H. 1995. The response of Dracocephalum moldavica L. plant to nitrogen fertilization and sowing density. Actahorticulturae, 390: 33-39

Fleming I, Michaelis UR, Bredenkotter D. 2001. Endothelium derived hyperpolarizing factor synthase (cytochrome P450 2C9) is a functionally significant source of reactive oxygen species in coronary arteries. Circle Research 88: 44-51

Garrat DC. 1964. The quantitative analysis of drugs. Chapman and Limited: Japan, $456-458$

Gyamfi MA, Yonamine M, Aniya Y. 2002. Free radical scavenging action of medicinal herbs from Ghana Thonningiasanguinea on experimentally induced liver injuries. Genetic Pharmacology, 32: 661-667

Halliwell B. 1995. Free Radicals in Biology and Medicine.4th edition. Oxford University Press. Oxford, UK, 13: 9780198568698

Hatano T, Kagaw H, Yasuhar T, Okuda T. 1988. Two new flavonoids and other constituentsinlicorice root: their relative astringency and radical scavenging effects. Chemical and Pharmaceutical Bulletin 36: 1090-2097

Hentschel V, Kranl K, Hollmann J, Lindhauer MG, Böhm V, Bitsch R. 2002. Spectrophotometric determination of yellow pigment and evaluation of carotenoids by high-performance chromatography in durum wheat grain. Journal of Agricultural and Food Chemistry, 50: 6663-6668

Ivanova D, Gerova D, Chervenkov T, Yankova T. 2005. Polyphenols and antioxidant capacity of Bulgarian medicinal plants. Journal of Ethnopharmacology, 96: 145-150 
Jahanban Sfahlan A, Mahmoodzadeh A, Hasanzadeh A, Heidari R, Jamei R. 2009. Antioxidants and antiradicals in almond hull and shell (Amygdaluscommunis L) as a function of genotype. Food Chemistry 115, 529-533.

Jing TY, Zhao XY. 1995. The improved pyrogallol method by using terminating agent for superoxide dismutase measurement. Progress in Biochemical and Pharmacology, 22: 84-86

Kakasy AZ, Lemberkovics E, Kursinszki L, Janicsak G, Szoke E. 2002. Data to the phytochemical evaluation of Moldaviandragonhead (Dracocephalummoldavica L., Lamiaceae). Herbal pharmacology, 48: 112-119

Le Bars D, Gozariu M, Cadden SW. 2001. Animal models of nociception. Pharmacological Reviews, 53: 597- 652 Lee JH, Talcott ST. 2004. Fruit maturity and juice extraction influences ellagic acid derivatives and other antioxidant polyphenolics in muscadine grapes. Journal of Agriculture and Food Chemistry, 52: 361-366

Lee J, Durst RW, Wrolstad RE. 2005. Determination of total monomeric anthocyanin pigment content of fruit juices, beverages, natural colorants, and wines by the $\mathrm{pH}$ differential method: collaborative study. Journal of AOAC International 88, 1269-1278

Lin-Chin YR, Huang CY, Wen KC. 2000. Evaluation of quantitative analysis of flavonoid aglycones in Gingko biloba extract and its products. Food Drug Analysis Journal, 8: 289296

Makari HK, Haraprasad N, PatilRavikumar HS. 2008. in Vitro Antioxidant Activity of the Hexane and Methanolic Extracts Of CordiaWallichii and CelastrusPaniculata. Aesthetic and Antiaging Medicine 1: 1-10

Nakayama T, Yamaden M, Osawa T, Kawakishi S. 1993. Suppression of active oxygen-induced cytotoxicity by flavonoids. Biochemical Pharmacology, 45: 265-267

Noda Y, Anzai-Kmori A, Kohono M, Shimnei M, Packer L. 1997. Hydroxyl and superoxide anion radical scavenging activities of natural source antioxidants using the computerized JES-FR30 ESR spectromoter system. Biochemistry, 42: 35-44

Nychas GJE, Skandamis PN. 2003. Antimicrobials from 821 Herbs and Spices. In Natural Anti-Microbials for the Minimal 822 Processing of Foods, Roller, S, Ed, Woodhead Publishing: Cambridge, 823 U.K, pp 176-200
Oyaizu M, 1986. Studies on products of browning reaction: antioxidative activities of products of browning reaction prepared from glucose amine. Journal of Nutrition 44: 307-315

Pagano P, Ito Y, Tomheim K, Gallop P, Tauber A, Cohen RA. 1995. An NADPH oxidase superoxide-generating system in the rabbit aorta. American Journal of Physiology 268: 2274-2280

Patricia I, Oteiza AG, Erlejman S, VerstraetenV, Keen CL, Fraga CS. 2005. Flavonoid-membrane interactions: a protective role of flavonoids at the membrane surface. Clinical and Developmental Immunology, 12: 23-25

Povilaityte V, Cuvelier ME, Berset C. 2001. Antioxidant properties of Moldavian dragonhead (Dracocephalummoldavica, L.). Journal of Agricultural and Food Chemistry, 8: 45-64

Povilaityte V, Venskutonis PR. 2000. Investigation of antioxidative activity of purple peril (Perillafrutescens, L.), Moldavian dragonhead (Dracocephalum moldavica, L.) and Roman chamomile (Anthemisnobilis, L.) extracts in rapeseed oil. Journal of American Oil Chemists Society, 77: 951-956

Proestos C, Sereli D, Komaitis M. 2004. Determination of phenolic compounds in aromatic plants by RP-HPLC and GC-MS. Journal of Agricultural and Food Chemistry, 75: 118-55

Rechinger H. 1986. Flora Iranica Labiatae, Akademische Druck Verlagsantalt. 150: 218-230

Ruch RJ, Cheng ST, Klauring JE. 1989. Prevention of cytotoxicity and inhibition of intercellular communication by antioxidant catechins isolated from Chinese green tea. Carcinogenesis Journal, 10: 1003-1008

Wiswedel I, Ulbricht O, Augustin W. 1989. Studies of lipid peroxidation in isolated rat heart mitochondria. Biomedicine Biochemistry, 2: 73-76

Sainani GS, Manika JS, Sainani RG. 1997. Oxidative stress: a key factor in pathogenesis of chronic disease. Journal of Medicine, 1: $1-20$

Zhao GR, Zhang HM, Ye TX, Xiang ZJ, Yuan YJ, Guo ZX, Zhao LB. 2008. Characterization of the radical scavenging and antioxidant activities of danshensu and salvianolic acid B. Food Chemical and Toxicology, 46: 73-81 